\title{
6. Indigenous Women and Mining Agreement Negotiations: Australia and Canada
}

\author{
Ciaran O'Faircheallaigh
}

\section{Introduction}

Agreements negotiated between mining companies and indigenous communities are increasingly important in setting the terms on which mining occurs on indigenous lands. This is particularly so in Australia and Canada, which are the focus of this chapter, but agreements are also becoming more widespread and important in developing countries. Their proponents view negotiated agreements as offering an opportunity to fundamentally change the distribution of costs and benefits from resource development. They argue that they do this by including provisions that limit the negative environmental, cultural and social effects of mining, and by allowing indigenous people to share in the wealth that mining creates (O'Faircheallaigh 2004: 303-4; Public Policy Forum 2005: 4-7).

There is a growing literature on the negotiation, content and outcomes of agreements between indigenous peoples and mining companies (see for example, AIATSIS 2008). This shows that some agreements are certainly generating large economic benefits for indigenous communities affected by mining, and are allowing indigenous landowners to effectively protect cultural sites and to have a substantial say in the environmental management of mining projects. In other cases agreements appear to offer indigenous groups limited benefits either by way of economic gain or enhanced protection of cultural and environmental values (Flanagan 2002; O'Faircheallaigh and Corbett 2005; O'Faircheallaigh 2006a, 2008).

Given the increasing importance of negotiated agreements and the uneven nature of the benefits they bring, it seems important to focus on the role of indigenous women in agreement making. Little has been written specifically about the role of women; the primary unit of analysis in most of the literature is the 'indigenous community' or the 'indigenous group'. To the extent that the role of women is discussed, the overwhelming impression both in the academic literature and in the publications of non-government organisations (NGOs) and community activists is that indigenous women are excluded from negotiations. The assumption that this is the case may help to explain the lack of a specific 
focus in the literature on the role of women. But is this assumption warranted? If it is not and indigenous women are in fact involved in negotiations, what roles do they play? Are they sufficiently involved to be able to shape agreements? If so, what is the impact of their involvement and are women contributing to positive outcomes where these occur? Are they sharing in the benefits generated by agreements?

These are not easy questions to answer. Many agreements are confidential, and the negotiations that lead to them even more so. This is in part because of formal confidentiality agreements between indigenous groups and mining companies, but also because communities may not want to reveal how they deal with negotiations, lest this weaken their hand in the future. Even where it is possible for researchers to gain access to formal negotiations, many critical decisions are taken away from the negotiating table, and the way decisions are revealed in a negotiation may indicate little about who was and was not influential in making them.

This chapter is both exploratory and, of necessity, based to some extent on my own work as a negotiator for indigenous communities, ${ }^{1}$ though I have also sought to draw on information available in the public domain. I begin by briefly summarising the existing writing on indigenous women and mining negotiations which, I argue, is oversimplified at least as it relates to Australia and Canada. This results in part from limited availability of information on negotiations, but also because too narrow a definition of 'agreement negotiations' is often adopted. I want to argue that this term in fact encompasses a great deal more than what happens across a table as company and community 'negotiators' hammer out an agreement, and that once this is recognised the role of indigenous women is both more complex and more substantial than the literature would suggest. In addition, the role of women very much depends on the specific structures used to prepare for, oversee and undertake the negotiation of agreements, and to conduct the ongoing negotiation that inevitably continues after an agreement is signed. In making this point I want to stress again the specific context I am discussing, that is, aboriginal societies in Australia and Canada. I recognise that the negotiation structures developed by indigenous groups in these countries may be quite different to those in other political and cultural contexts.

1 That work spans nearly 20 years and involves assisting groups to prepare for and undertake negotiations in a variety of legal, political and economic contexts including Cape York, Central Queensland, North Stradbroke Island, the Mount Isa region, the Hunter Valley, the Northern Territory, the Kimberley and the Pilbara in Australia and Nunavut in Canada. 


\section{Exclusion of Women from Mining Negotiations}

The overwhelming impression gained from a review of the existing published information is that women are largely and often entirely excluded from negotiating mining agreements. For instance in a review of corporate engagement with indigenous women in the minerals industry, Gibson and Kemp (2008: 107) note a number of cases in Australia, Papua New Guinea (PNG), Indonesia and India where women were inadequately represented in or excluded from negotiations. They also note that inclusion on negotiating teams does not mean that women are free to contribute equally. They finish their brief discussion of the topic by noting the limited extent of information on negotiations, and say that 'Indigenous women in negotiations about mineral development is a fertile area for further research' (ibid.). Kambel (2004: 1) refers to cases that 'document the exclusion of Indigenous women from negotiations and decision making processes relating to their lands and territories, because of erroneous assumptions that this was a man's task.' In the Canadian context, Hipwell et al. (2002: 12) say that maledominated band councils have usurped the traditional power of women with the result that 'the voices of women are often marginalised' in negotiations. In Indonesia, according to Simatauw (2002: 38-9) women have been marginalised in negotiations with PT Freeport, and denied the right to receive or manage payments made by the company, with the result that "payments are inclined to benefit men and reduce the roles of women within the community.'

In discussing negotiations in PNG, Bonnell says:

To date in PNG, all negotiations and decisions regarding mining development have been made by men. In the recently developed forum process [for approving new mining projects], agreements were made between the mine developer, the provincial national and local level governments and the local landowners association. They are all men (Bonnell 1998: 3).

Martha Macintyre, also writing about PNG, states: 'Despite women's legal right to participate in this process [setting the nature of mining arrangements], their voices are rarely heard and they exert very little influence on the miners, politicians and governments who make the decisions about mining projects' (2002: 26). Speaking specifically about the Lihir gold mine, she says: 'Lihirian women played almost no role in negotiations over the mining lease' (2003: 123), and that 'women were excluded from the formal negotiation process. Although they were occasionally consulted by the company's community relations department, women were not represented on the relevant committees and were forced to rely on men to represent their interests' (2002: 27). Byford (2002: 30-1) states that Misima women were excluded from mining negotiations and that 
as a result 'royalties and compensation payments were invariably paid to the men involved in the negotiations.' Wardlow, discussing gold mining in the PNG highlands, states that 'women do not act as landowner representatives in interactions with the company' (2004: 56), although elsewhere in the same article (ibid.: 63) she refers to two individual women who have been very active' in mining negotiations.

A recent roundtable, held by the International Union for the Conservation of Nature (IUCN) and the International Council on Mining and Metals (ICMM) on indigenous peoples and mining companies, noted one case where a project went ahead where the traditional ownership of land was vested in women 'but women were not included in negotiations and received no direct benefits' (IUCNICMM 2008: 10). A 2004 review of the current status of indigenous women by the United Nations Permanent Forum on Indigenous Issues (UNPFII 2004: 2) sets the issue in a broader context, stating: 'Indigenous women around the world ... agree on one of their greatest mutual concerns: the negative impact of their exclusion from decision making processes that affect them'. It goes on to discuss the specific case of gold mining on Misima Island in PNG, where it claimed that mining company officials chose to negotiate only with male members of the community, 'even though the women owned the land. The result was that the royalties the company eventually paid went directly to the men, and the women had no say over how the money was spent' (ibid.: 3; see also CERD 2004: 6, 26-7).

Similar views emerge from NGOs and activists who focus on the mining industry. The former Oxfam Mining Ombudsman, Ingrid Macdonald, has stated (2003: 6) that the gender impacts of mining include 'companies entering into negotiations only with men, making women neither party to the negotiations, nor beneficiaries of royalties or compensation payments, even in matrilineal societies where women are the culturally recognised landowners'. The campaign against environmentally destructive gold mining, No Dirty Gold (2008), claims: 'Women are often excluded from community negotiations with mining companies', while Friends of the Earth Europe (2008) refers to 'the exclusion or marginalisation of women from negotiation with mining companies regarding project design, mining royalties and compensation systems.' The International Women and Mining Network (IWMN) (RIMM 2004) has called on companies and governments to 'ensure that there is active participation of local women affected by a mining project in decision making,' and say that they 'must take direction from local women about the appropriate ways for ensuring that their views are heard'.

How accurate is this view of exclusion? In my experience, it certainly oversimplifies the situation. In at least some cases indigenous women have in fact played key roles in mining negotiations. This is not to deny that exclusion 
does occur, but if we are to support, for instance, the call of the IWMN to ensure that there is active participation by indigenous women, it is essential to examine those cases where women do participate effectively, so as to understand why and how it is possible.

If we begin by focusing on the conduct of formal negotiations between indigenous communities and mining companies, there are instances where women have been central. In Canada, for instance, a number of indigenous women have held the position of chief negotiator. To a greater extent than in Australia, agreement negotiations in Canada tend to be organised around the role of chief negotiator, a single individual who has responsibility for the overall conduct of negotiations, under the direction of the relevant decision-making body (which may be a chief in council, or an entire community, as occurs where agreements are the subject of a plebiscite before they can be signed). A number of women have held this role, including the Inuit chief negotiator for the Voisey's Bay impact and benefit agreements (IBAs), signed between Inuit and Innu groups and Inco (now Vale Inco); and for the environmental agreement signed between the groups and the Newfoundland and Canadian governments. The Voisey's Bay agreements are certainly among the most significant signed by indigenous communities in recent years, both because of the scale of economic benefits they bring (revenues of many million dollars a year; and indigenous employment levels among the highest achieved at any large mine in Australia or Canada), but also because of their innovative and extensive provisions regarding indigenous participation in environmental management. Indigenous women have also acted as chief negotiators for major agreements in the Northwest Territories, where one of the Dene communities there, Lutsel K'e, used women negotiators on its agreements with a number of diamond mining companies over the period since 1996 (Bielawski 2003; Weitzner 2006: iii, 12).

Turning to Australia, women played a direct and key role in negotiating the agreement between Argyle Diamonds Ltd and the traditional owners of the Argyle diamond mine in Western Australia from 2002 to 2005. In this case negotiations were conducted by a 'coordinating committee', drawn from all of the native title groups with an interest in the land covered by Argyle's tenements, and supported by a team of logistical staff and technical advisers provided by the Kimberley Land Council (KLC). Key negotiating sessions focused on two or three day meetings between traditional owners, the KLC and the mining company. A majority of coordinating committee members from the key traditional owner groups were women (Argyle Diamonds Limited et al. 2005), and women played a central role in presenting negotiating positions to the company and in pushing for their acceptance. Since 2005 the KLC has supported traditional owners in 
negotiating three further mining agreements, and in each case agreements have been concluded by negotiating teams that involved substantial participation by women traditional owners.

The negotiations just referred to, it should be stressed, are very substantial in terms of the scale of the projects and investments involved. Also, while Gibson and Kemp (2008) are correct to point out that inclusion of women on negotiating teams does not mean that women are free to contribute equally, in these cases women played central roles, including that of chief negotiator.

Thus the picture of almost total exclusion is oversimplified, at least as it applies to Australia and Canada. This strongly suggests that research focusing on the experience of women involved in these negotiations, on the conditions that made their involvement possible, and on the impact of their participation on negotiation processes and outcomes, would be valuable.

\section{Negotiations: Much More Than Sitting Across a Table}

It is also important to look more critically at the concept of 'negotiation' as it applies to mining agreements, in order to fully appreciate the extent to which indigenous women are or are not involved. None of the literature that focuses on the exclusion of indigenous women from negotiations explicitly defines what the process of 'negotiating' a mining agreement actually involves. The general and implicit assumption appears to be that negotiation involves a process of (usually formal) discussion, in which representatives of the parties (mining companies, affected indigenous groups and in some cases government) exchange positions and, over time, reach an agreement that represents the end point of the negotiation. It can be argued that negotiation in fact involves much more than this.

First, and critically, agendas for negotiations must be set. Each party must decide what it will seek to extract from the negotiations, and what it is prepared to concede in order to extract it; in other words what issues to 'put on the table' and how hard to fight for them. As the process of negotiation unfolds, additional, often difficult, decisions have to be made about which issues are vital and on which concessions cannot be made; and which issues can be the subject of compromise. In the wider context of policy making, it has long been recognised that the capacity to control or influence the agenda for decision-making, to determine which issues are 'on the table' and which are not, is critical; and indeed in many cases more important than the capacity to determine outcomes in relation to the issues that do make it on to the table (Bachrach and Baratz 
1963; Lukes 1974). The same applies in negotiations. Being a negotiator confers little power if the matters you regard as most important are not on the agenda, or are 'sacrificed' to achieve gains in other areas. On the other hand being able to set the agenda for negotiations confers considerable influence, even if one never sits at a table playing the role of 'negotiator'.

Indigenous women have played a critical role in setting the agenda for a number of major negotiations in Australia and Canada. One example involves negotiations in relation to Comalco's bauxite mining operations at Weipa in Western Cape York, Queensland. By the mid-1990s Comalco had been mining at Weipa for nearly 40 years without the consent or support of aboriginal traditional owners. It initiated negotiations for an agreement in 1996, in part because of policy changes by its parent company, Rio Tinto; and in part because of planned expansions to its mining operations that, though legally sanctioned, might be threatened by the absence of an agreement. An extensive community consultation exercise was undertaken with the support of the regional aboriginal organisation, the Cape York Land Council (CYLC), and under the direction of three steering committees representing the aboriginal communities affected by Comalco's operations (O'Faircheallaigh 2000, 2005). Each committee included a substantial number of women, and in two they outnumbered men by three to two. The committees oversaw the consultations and preparation of economic and social impact assessments that documented the history of Comalco's presence on Cape York and the aspirations and concerns of community members in relation to future mining operations. On this basis a negotiating position was developed and approved by the three committees and, subsequently, by large community meetings.

Women played a critical role in setting the agenda for negotiations. For instance, as a result of their input, the negotiating position emphasised heavily what they characterised as 'recognition and respect'. In their view, much of the negative impact of mining on their community resulted from a fundamental failure by Comalco to afford them recognition as traditional owners. An agreement would have to include a series of measures designed to change this situation, including Comalco's adoption of a corporate policy explicitly affording aboriginal people that recognition, cross cultural awareness training for all Comalco employees, dissemination of information on land ownership in the non-aboriginal community, support for cultural activities and renaming places in the vicinity of the mine with their correct aboriginal names.

The steering committees continued to play a central role as the negotiations developed. For instance, both the communities and the mining company were agreed that provisions governing the use of royalties paid to traditional owners should be determined before an agreement was signed, in order to avoid community conflicts that might develop if no arrangement was in place 
for royalty distribution when payments commenced. In a series of steering group and community meetings women played a key role in pushing for, and achieving, a trust structure under which a substantial proportion of revenues would be allocated to a long term investment fund, creating a sustainable source of benefit for the communities that could outlast bauxite mining.

For much of the time the group which engaged in face-to-face 'negotiations' with Comalco did not include any indigenous women (although senior women traditional owners did become involved at critical junctures). But to focus on this group and so decide that indigenous women were 'excluded' from the negotiations would be misleading. Aboriginal women played critical roles in determining how a negotiating position would be developed, in shaping the content of that position and in deciding how the financial benefits flowing under an agreement would be utilised. In this way they had a large impact on the eventual outcomes of negotiations (for a summary of the agreement, see Cape York Land Council and Comalco 2001; O'Faircheallaigh 2005).

Women also played a key role in shaping agendas for the Voisey's Bay negotiations, as mentioned earlier. Voisey's Bay is located in the Canadian province of Labrador where the territories of two distinct groups of aboriginal people overlap. The Labrador Inuit are the most southerly of the Inuit nations, while the Innu are the most easterly of the nation of the Algonquin language group. Represented by the Labrador Inuit Association (LIA) and the Innu organisation, Innu Nation, respectively, each conducted separate negotiations and concluded separate agreements with Voisey's Bay Nickel Company (VBNC), a subsidiary of Inco Ltd. Nevertheless, they worked together closely, sharing information and jointly undertaking direct action and litigation to support their negotiating effort.

Prior to undertaking negotiations, Innu Nation established an Innu Nation Task Force on Mining Activities (INTFMA), comprised of three representatives from each of the two Innu communities, 'to provide input into the Innu's decisionmaking processes regarding [Voisey's Bay]' (INTFMA 1996: 4). The Task Force conducted an extensive process of information dissemination and community consultation, designed to establish Innu aspirations and concerns in relation to mining in general and the Voisey's Bay project in particular. It undertook numerous one-on-one interviews with community members, speaking to approximately equal numbers of men and women (ibid.: 10), and organised small group discussions, information sessions and open community meetings.

The Task Force consultations revealed widespread and deeply felt concerns about the damage mining might cause to land, water and wildlife; and about the negative effects of such damage on the Innu's ability to practice and sustain their culture. Innu had little faith in the willingness or ability of the company or the government to prevent environmental damage, and believed that only 
their own involvement in decisions about the project could protect the land and its resources. Concern was also raised about damage to Innu cultural heritage, especially burial sites; about the inability of Innu to access the Voisey's Bay area; and about the impact on wildlife of hunting by mineworkers. The prospect of additional jobs and business opportunities was widely welcomed. However, many respondents believed that most such opportunities would accrue to people from outside the region and that jobs obtained by Innu would generally be menial and poorly paid. Concerns were raised that the pace of project development was too rapid to allow appropriate Innu involvement in decisionmaking, and that the absence of sufficient lead time would make it impossible to train Innu for more highly skilled and better paid positions (INTFMA 1996). The Task Force produced a comprehensive Final Report detailing the benefits and costs community members believed would be associated with mining, and identifying strategies for mitigating negative impacts and maximising positive ones (ibid.).

The LIA undertook a variety of consultation processes to establish its members' goals and priorities in relation to the IBAs. These included Inuit submissions and presentations to the Environmental Review Panel for Voisey's Bay, and the activities of the Tongamiut Inuit Annait (TIA), the organisation representing Inuit women in northern Labrador. The TIA convened a number of workshops on mining agreements, on the environmental review process and on Canada's comprehensive land claims policy. It lobbied to ensure that these processes and policies would include a focus on issues of key interest to Inuit women; and more specifically, it lobbied the LIA on the need for gender equality provisions in mining agreements with Inco/VBNC, and had gender equality provisions drafted for the LIA to include in its negotiations with the company. TIA was informed that Inco rejected these provisions. Archibald and Crnkovich (1999: 28) report that the TIA was not told the reason for the rejection, and that it was unclear whether there were opportunities to negotiate alternative wording or whether some of the provisions could have been achieved at the expense of others. They argue that 'women's representatives, if present, could have advanced the arguments on their own behalf'. In fact, however, gender equality provisions are included in the Voisey's Bay agreements, so it would appear that the Innu and Inuit negotiators refused to concede to Inco/VBNC's rejection of them. This highlights the fact that a capacity to influence negotiation agendas and priorities is extremely important. It supports a key argument of the paper, that a complete assessment of women's role in negotiations must include their influence on these agendas and not just whether they are present at or absent from the negotiating table. Having said that, it must also be remembered that the Inuit chief negotiator was a woman! 
Many of the aspirations and concerns arising from the Inuit consultations were identical to those identified by the Innu Nation Task Force (see, for example, Archibald and Crnkovich 1999: 14). These consultative processes represented a critical foundation for Innu and Inuit negotiators in their discussions with Inco/ VBNC and with Canada and Newfoundland. This is evident from the content of the (separate) IBAs they signed with Inco/VBNC, and the Environmental Management Agreement they jointly signed with the governments of Newfoundland and Canada. In combination, these comprise a comprehensive package of measures designed to address the concerns and realise the aspirations expressed by Innu and Inuit women and men (Lowe 1998; Innes 2001; LIA 2004: 17-8; Gibson 2006; O'Faircheallaigh 2006b: 49-57, 175-95).

They include a provision, unique in my experience in indigenous agreements with mining companies, under which Inco/VBNC agreed to develop Voisey's Bay at a scale much smaller than it originally intended. This provision substantially reduced its environmental impact and allowed Innu and Inuit people a much longer period over which to develop the capacity to take full advantage of employment and business opportunities. They also provide for Innu and Inuit involvement in government environmental permitting procedures for Voisey's Bay, and a direct role for Innu and Inuit in monitoring the impact of Inco's mining operations. In addition, they contain extensive and detailed provisions designed to enhance employment opportunities. The latter include several commitments by the company: to promote equality of Innu and Inuit men and women; to work with the LIA and the Innu Nation to identify and remove any barriers to the employment and advancement of Inuit and Innu, particularly Innu and Inuit women; to provide gender sensitivity training for the project workforce; and to report on a quarterly basis on the number of Innu/Inuit women hired. The agreements guarantee access for Innu and Inuit to the Voisey's Bay site for hunting and cultural activities, and provide for the protection of Innu and Inuit heritage resources. They also provide for rotation schedules, a cultural leave policy and job-sharing, to facilitate the practice of traditional activities; and prohibit workers from bringing firearms on site and from hunting, fishing or trapping during their employment rotation.

The Argyle negotiations provide a third example. Here women did, as mentioned earlier, play a direct role in negotiations, but in addition were very influential in setting agendas, and also in deciding where concessions would or would not be made in negotiations. The coordinating committee shaped the agenda for negotiations by developing, with the assistance of their support staff, what they called 'traditional owner rules' on each key issue they wished to negotiate about. In some cases these were only half a page in length, but these rules set out core positions in a form that enabled people to refer to them easily, and quickly assess company positions against them. In particular, one issue 
pushed by women members of the steering committee related to the protection of significant sites. To appreciate this issue, some background on the Argyle project is required.

The Argyle diamond deposit was discovered in 1979, on an escarpment that held a site of considerable spiritual and cultural significance, especially for women. The site was registered with the Western Australian Museum, and the Argyle traditional owners sought to use this fact to secure its protection from mining. However, under Section 18 of the Western Australia's Aboriginal Heritage Act 1972, a mining company could apply to the relevant government minister to 'vary the use' of the site, which in the context of mining meant to damage or destroy it. The mining company did this, and received ministerial approval to mine on the site. As the Argyle mine was developed, the location of 'barramundi dreaming' site was destroyed. Its destruction resulted not just in great anguish to its traditional owners, but also in serious social tensions and major repercussions for the women who were the site's primary custodians (Dixon and Dillon 1990).

Given this history, coordination committee members were determined to use the opportunity offered by the negotiations with Argyle Diamonds Ltd to ensure that there would be no repeat of the episode on other parts of the company's lease. They therefore included in the 'rules for cultural heritage' a rule they referred to as 'No means No'. In other words, they sought an undertaking from the company that if traditional owners took the view that an area should not be explored or mined, the company would accept this position and would not apply for ministerial permission to damage the site under the Aboriginal Heritage Act. Women members of the coordinating committee fought hard for acceptance of this provision in negotiations, and, when it proved necessary to do so, made decisions about what concession should be made in order to achieve the 'No means No' rules. They were successful, and the Argyle agreement became the first in Western Australia to include such a provision (Argyle Diamonds Limited et al. 2005). Since then a number of other traditional owner groups in Western Australia have achieved a similar outcome in negotiations (KLC 2008).

\section{Post-Agreement Negotiations}

These examples illustrate the central importance of the agenda-setting processes that precede and set the framework for formal negotiations leading to the signing of an agreement. Equally, it is important to recognise that negotiations between mining companies and indigenous groups do not stop when agreements are concluded. In addition, structures established as a result of agreements help to determine the allocation of benefits and costs from agreements and more broadly 
from the projects to which they relate. Both the operation of these structures and ongoing negotiations with companies create further possibilities for the inclusion and exclusion of women.

Agreements create a framework for interactions between indigenous people and companies in relation to mining and related activity on indigenous land. Parts of this framework may be specific and leave little room for subsequent adaptation or interpretation; for example, in the case of financial payments mandated by an agreement. But in many other areas, an ongoing process of negotiation must occur as agreements are implemented and modified, either formally though legal amendments or, much more commonly, through the mutual acceptance of policies and practices that are seen to generate better outcomes for both parties (O'Faircheallaigh 2002; Crooke et al. 2006; for specific examples of this process unfolding, see Gelganyen Trust, Kilkayi Trust 2006: 13-5; Rio Tinto 2008: 20-2, 38-40).

For instance, provisions of agreements designed to provide indigenous training and employment opportunities may set broad goals, indicate a range of initiatives that may be taken to pursue these goals and include an overall commitment of resources by the company. But which specific initiatives should have priority? What should be done if a particular initiative mandated by an agreement proves ineffective? Rarely will either party wish to reopen the agreement to provide for a different approach. This is much more likely to be negotiated informally by company employees and traditional owners 'on the ground'. Regimes established to ensure the protection of aboriginal sites provide another example. The specific requirements contained in an agreement may prove less than ideal for either or both parties, and alternative and more practical alternatives will be agreed. Environmental management provisions in agreements often provide that traditional owners will be consulted about major project changes or about proposed amendments to environmental regimes, and that mine operators will take account of their views (O'Faircheallaigh and Corbett 2005). But how are they to be consulted? How are their views taken into account? To what extent will companies modify their plans? All of these are matters for negotiation.

A full assessment of the role of women in negotiating agreements must also focus on this area. To date it has almost entirely escaped the attention of researchers, but it is clear that in Australia and Canada their role is far from negligible, and indeed in some cases it is central. The issues just discussed are usually handled by joint company - indigenous 'coordination committees' or 'implementation committees' established under agreements, and women often play a key role in these committees. This has certainly been the case with the committees for the Argyle and Comalco Agreements, with both having substantial numbers of women members and having been chaired by aboriginal women. In addition to 
implementation committees, the Voisey's Bay IBAs provide for the appointment of full time implementation coordinators, and a number of these have been indigenous women, including the current coordinator for the Inuit IBA.

An anecdote, not related to any of the negotiations discussed elsewhere in the chapter, will further illustrate the role of women in this area, and their keen appreciation that negotiations do not end with the signing of an agreement. It involves a major new project in north Australia being developed by a multinational mining company. Negotiations proceeded smoothly, reflecting both the urgency the company faced in reaching an agreement and the fact that the senior company manager responsible for negotiations, and who would also oversee the project's construction, quickly established a reputation for integrity and straight talking. The agreement signing ceremony was in full swing on a beach near the project site when it was noticed that the senior manager and some of the women elders had disappeared. It transpired that they had taken him to a spring further along the beach, and given him a traditional baptism and an aboriginal name. During the period that followed, senior women often had to engage the manager about practical issues related to implementing the agreement. Each time they met him they would greet him by his aboriginal name, and this clearly affected the way he dealt with them. The toughness evident in his dealings with project contractors, union officials and male indigenous leaders was not nearly as obvious, and there always seemed to be a way in which the needs of the women could be accommodated. I am not suggesting that the women's action was cynical; rather it was seen by them as an appropriate way to mark a milestone in their relationship with the manager. But this is precisely the point. The agreement was just a marker; relationships would continue to be negotiated, and they had created a firm foundation on which to ensure that the results of the negotiation would be mutually beneficial.

Examples of structures established under agreements that help determine the allocation of benefits and costs include the trusts often established to manage royalty payments made by project operators, and the environmental monitoring agencies established under a number of Canadian agreements. The trusts created pursuant to the Argyle, Comalco and Voisey's Bay agreements handle millions of dollars in revenues a year (A \$6 million in Argyle's case in 2007, for example, and tens of millions of Canadian dollars in 2008 for the Innu and Inuit Voisey's Bay trusts), investing a proportion in long-term capital funds and allocating the remainder to social and economic development in affected communities. All three have had substantial numbers of women trustees, four out of nine in Argyle's case during 2005-2008. The Argyle trusts initially had a woman as deputy chair, and now both co-chairs of the trusts are women. In the case of the Comalco trust, women have served as chairs both of the main trust and of regional trusts that manage the distribution of benefits at the community level. 
Structures of this sort are critical in determining whether women share in the benefits of agreements. For instance, the Argyle traditional owners decided to use some of the funds flowing under the agreement to establish a 'Law and Culture' capital fund. The fund is invested in low to medium risk investments to ensure a steady income, and its capital must be preserved. The capital fund, and the income from it, is split evenly between men and women to support their respective cultural activities, and income distributed from it can only be used for this purpose (Gelganyen Trust, Kilkayi Trust 2005: 13).

An example of an environmental agency is the Environmental Management Advisory Board (EMAB), established pursuant to an environmental agreement between Diavik Diamond Mines Incorporated (DDMI), a subsidiary of Rio Tinto and operator of the Diavik diamond mine; five aboriginal groups; and the governments of Canada and of the Northwest Territories. Among the agreement's purposes are to ensure that environmental mitigation measures are appropriately implemented; to undertake additional monitoring to verify the accuracy of environmental assessment and the effectiveness of mitigation measures; and to facilitate the effective participation of aboriginal peoples in achieving these purposes. EMAB's roles include serving as a public watchdog over the environmental regulatory process, and implementing the environmental agreement. It consists of one representative nominated individually by each of the five aboriginal groups, governments of Canada and the Northwest Territories and DDMI.

Since its establishment in 2002 the Board has, for instance, found fault or raised concerns about the way in which Diavik notified regulators of changes to its dike design; about its wildlife monitoring and aquatic effects monitoring programs; its contribution to cumulative effects monitoring; and what the Board saw as DDMI's uncoordinated approach to site visits by aboriginal elders. The Board has also been critical of government regulators, for their perceived failure to maintain adequate inspection of Diavik's operations; to review documents in a timely manner; and to provide sufficient opportunity for the aboriginal communities to comment on license applications. Thus, the Board plays an important role in seeking to ensure that the environmental agreement helps minimise negative environmental impacts from mining, and provide aboriginal people with a real say in environmental management. ${ }^{2}$

In this area also, indigenous women have been active. For example, the Board has drawn on the advice of women elders in developing proposals on how to approach environmental and wildlife management issues, and it has involved

2 For details on the Board's roles and activities, see O'Faircheallaigh (2006b: 29-34). 
them in environmental monitoring activities. A number of aboriginal community representatives on the Board have been women, and the Board's current Vice Chair is a Lutsel K'e woman, Florence Catholique (EMAB 2004, 2007).

\section{Explaining Opportunities for Participation}

While women may be excluded from negotiations in some situations, this is not always the case. What explains these divergent outcomes?

Cultural context is obviously important. For instance, in some regions of PNG, where much of the specific evidence for the exclusion of women in the current literature originates, cultural factors inhibit women's participation. As Macintyre (2002: 28) says: 'The exclusion of women from all-important decision-making ... is almost exclusively due to the weight given to Papua New Guinean men's views on "tradition" and the customary role of women.... Mining companies are reluctant to champion women and risk offending "custom"'. In relation to historical traditions on Lihir Island, "The ritual and political centre of each village was the men's house. There is no evidence that in the past women had any more control over land or ritual events than they do today. Old women report that ... male authority [was] less contested than it is now...' (Macintyre 2003: 120).

In contrast, traditionally in many parts of Australia, both men and women had central but separate roles in 'public' spheres related to cultural and religious practices. This separation, while giving 'women's business' particular focuses that may be different from men, 'nevertheless operates in an understanding of the public good in which women have particular and crucial responsibilities' (Edmunds 1996: 127). In Hamilton's words, 'men hold and care for one segment of mythology, and stress particular themes and events in their myths; women hold and care for a complementary set' (cited in Edmunds 1996: 126). This situation certainly applies, for instance, in the Kimberley region where the Argyle diamond mine is located (Rose 1996: 36-7). In the contemporary context, while men may be more inclined to take a public stance, 'men and women continue to maintain their separate but complementary spheres' (Edmunds 1996: 131; see also Rose 1996, 2001; Langton 1998; Kopasur 2002: 14). This situation clearly provides a much stronger basis on which women can exert a major influence on mining negotiations, and it is a situation that is certainly not unique to Australia (Brody 2000: 265-7; Carino 2002: 16).

A second critical issue involves decision-making processes in relation to mining negotiations. One matter involves the openness of those processes and the opportunities they offer for participation. On the indigenous side, the process leading to decisions about what issues to pursue, and how hard to pursue them, 
can occur through an extensive process of community consultation, deliberation and endorsement that generates a negotiating position which is presented to the mining company. At the other end of the spectrum, it can involve a small group of indigenous people, or even a single person, deciding unilaterally what position to pursue in negotiations. The way in which 'hard' decisions are taken as a negotiation proceeds can similarly vary. To the extent that processes are 'open', the participation of women will be facilitated. In each of the cited examples where women played a key role in setting negotiation agendas and generally in decision-making, the processes involved provided extensive opportunity for community participation and also, in the Australian cases, the establishment of steering committees or similar bodies with broad representation that oversaw the conduct of the negotiations.

The processes discussed share two other important characteristics related to the issue of participation. The first is time. In each case substantial amounts of time were available in which to prepare for negotiations. In the Argyle and Comalco negotiations, this was in part because they involved existing operations and so the pressure of tight project development schedules was absent. In the Voisey's Bay case, the aboriginal groups refused to negotiate until they had undertaken their preparations in the way they wished. The second factor involves resources. Again, in these three cases substantial budgets were available, either from the companies involved or government or a combination of both, to support broadly based consultations and the operation of representative structures. These circumstances applied, in part, because in every case aboriginal political organisations existed (the CYLC, the KLC, the LIA and the Innu nation) that could insist on appropriate time frames and resources and then apply those resources effectively.

Mining company policies can also play a role, and a number of authors highlight the tendency of company representatives to focus on men, and their unwillingness to challenge cultural practices that exclude women (Byford 2002: 30-1; Macintyre 2003: 123). However, their role is secondary in that they tend to adapt their policies to prevailing legal, policy and institutional contexts (Simatauw 2002: 36; Macintyre 2002: 29). This is illustrated by the fact that the same companies have adopted quite different approaches to agreement making in different situations (O'Faircheallaigh 2008: 45).

No one of the factors just discussed is sufficient to guarantee substantial participation by women, and neither does the absence of any one factor rule it out. For example, in negotiations surrounding the first diamond mine in Canada's Northwest Territories, in a context where there was no clear legal requirement for BHP to negotiate, the federal government imposed a 60 day time limit on negotiations. This move, combined with a paucity of resources, created enormous problems for some of the aboriginal communities involved. 
Yet indigenous women still played a major role in the negotiations (Bielawski 2003; Weitzner 2006). Conversely, according to Byford (2002: 30) Misima women have been excluded from mining negotiations despite the fact that, historically, they controlled key economic resources and have been able to 'assert their status independently of men'. Overall, however, it appears that the presence of these factors enhances participation by women, while their absence militates against it.

These same factors work to determine the extent to which indigenous communities as a whole benefit from mining negotiations. Research on the extent to which agreements reflect indigenous interests shows clearly that, in addition to the prevailing legal context, critical influences are the presence of a strong indigenous political organisation; the mobilisation of a united community to support the negotiation effort; and the resources that the organisations can marshal and apply, including to allow community mobilisation (Gibson 2006; O'Faircheallaigh 2006a, 2008). Thus, the factors that facilitate participation of women in negotiations are precisely those that generate positive outcomes for communities from negotiations. This highlights an important point. To the extent that communities take the steps necessary to achieve positive outcomes, they will facilitate the participation of women. To the extent that they act to facilitate the participation of women, they will also help to secure positive outcomes for the community as a whole.

\section{Conclusion}

There has been little research focusing specifically on the participation of indigenous women in negotiating mining agreements, and there is obviously a need for additional work in this area (Weitzner 2002: 66; RIMM 2004; Gibson and Kemp 2008). That work must be informed by an understanding that much more is involved in negotiating agreements than sitting across a table from mining company representatives. A focus on the interaction between negotiators from each side is appropriate, but it is not sufficient. It is also essential to focus on the processes that set negotiation agendas and determine priorities as negotiation proceed; on the ongoing negotiations that inevitably continue after an agreement is signed; and on the operations of organisational structures established as a result of negotiated agreements. All of these play critical roles in determining the allocation of benefits and costs from agreements and projects and their impacts on women, and so each deserves careful attention.

Particularly when 'negotiations' are seen in this broader context it is clear that, at least in Australia and Canada, indigenous women are not generally excluded from negotiations. The examples cited here do only involve a limited number of 
projects, but they are highly significant in terms of the wealth they generate and in establishing benchmarks in achieving recognition for aboriginal landowners, and ensuring that negative cultural and environmental impacts are minimised (see, for example, Crooke et al. 2006: 111). In the cases discussed women have not been excluded or marginalised. This does not mean that they have always participated on a basis of complete equality with men, but they have played key and in some cases dominant roles at the negotiating table, in setting negotiation agendas and in the operation of structures established under agreements. Their participation is reflected in the content of agreements and in the distribution of benefits from them, for instance in the inclusion of gender equity provisions in the Voisey's Bay agreements; in the emphasis on traditional owner control over sites (the 'No means No' rule) in the Argyle agreement; in the equal distribution between men and women of income from the Argyle cultural trust; in the emphasis on recognition and respect for traditional owners in the Comalco agreement; and in the allocation of a large part of revenue under the Comalco agreement to creating a sustainable capital fund. It is not, it should be stressed, that aboriginal men opposed these initiatives, but the presence of women and the pressure they generated was critical to their adoption.

The general circumstances that have created the opportunity for women to play a forceful role in negotiations include the existence of legal structures creating opportunities for indigenous groups to negotiate; and specific cultural contexts that are conducive to, or at least do not prohibit, the participation of women. Other vital and more specific factors include the use of processes to prepare for negotiation that emphasise broad community participation and political mobilisation; the availability of sufficient time and resources to ensure that opportunities for participation can actually be realised by women; and the existence of indigenous organisations capable of insisting on appropriate timelines and applying resources effectively. Where these factors operate, they work not only to facilitate women's participation in negotiations but also to enhance the benefits that indigenous communities as a whole gain from them.

\section{References}

AIATSIS (Australian Institute of Aboriginal and Torres Strait Islander Studies), 2008. 'Native Title Payments \& Benefits: Literature Review.' Canberra: AIATSIS.

Archibald, L. and M. Crnkovich, 1999. If Gender Mattered: A Case Study of Inuit Women, Land Claims and the Voisey's Bay Nickel Project. Ottawa: Status of Women Canada. 
Argyle Diamonds Limited, Traditional Owners and Kimberley Land Council Aboriginal Corporation, 2005. 'Argyle Diamond Mine Participation Agreement - Indigenous Land Use Agreement.' Perth.

Bachrach, P. and M.S. Baratz, 1963. 'Decisions and Non-decisions.' American Political Science Review 57: 641-51.

Bielawski, E., 2003. Rogue Diamonds: Northern Riches on Dene Land. Vancouver: Douglas and McIntyre.

Bonnell, S., 1998. 'Impact of Mining on Women.' Paper presented at conference on 'Papua New Guinea Mining and the Community', Madang, 26-29 July.

Brody, H., 2000. The Other Side of Eden: Hunters, Farmers and the Shaping of the World. Vancouver: Douglas and McIntyre.

Byford, J., 2002. 'One Day Rich: Community Perceptions of the Impact of the Placer Dome Gold Mine, Misima Island, Papua New Guinea.' In I. Macdonald and C. Rowland (eds), op.cit.

Cape York Land Council and Comalco, 2001. 'A Way Forward Together.' Press Release, 11 March.

Carino, J.K., 2002. 'Women and Mining in the Cordillera and the International Women and Mining Network.' In I. Macdonald and C. Rowland (eds), op. cit.

CERD (Centre for Environmental Research and Development), 2004. 'Echoes in the Wilderness: Mining, Women and Communities Workshop August 2004.' Boroko: CERD.

Crooke, P., B. Harvey and L. Langton, 2006. 'Implementing and Monitoring Indigenous Land Use Agreements in the Minerals Industry: The Western Cape Communities Co-existence Agreement.' In M. Langton, L. Palmer, K. Shain and O. Mazel (eds), Settling with Indigenous People: Modern Treaty and Agreement Making. Sydney: The Federation Press.

Dixon, R. and M. Dillon (eds), 1990. Aborigines and Diamond Mining: The Politics of Resource Development in the East Kimberley. Nedlands: University of Western Australia Press.

Edmunds, M., 1996. 'Redefining Place: Aboriginal Women and Change.' In R. Howitt, J. Connell and P. Hirsch (eds), Resources, Nations and Indigenous Peoples: Case Studies from Australasia, Melanesia and Southeast Asia. Melbourne: Oxford University Press.

EMAB (Environmental Monitoring Advisory Board), 2004. 'Annual Report 2003/2004.' Yellowknife: EMAB. 
, 2007. 'Annual Report 2006/2007.' Yellowknife: EMAB.

Flanagan, F., 2002. 'Pastoral Access Protocols: The Corrosion of Native Title by Contract.' AIATSIS, Canberra (Native Title Research Unit Issues Paper 2(19)).

Friends of the Earth Europe, 2008. 'Extractive Industries: Blessing or Curse?' Viewed 17 october 2008 at www.foeeurope.org/

Gelganyen Trust, Kilkayi Trust, 2005. 'Future, Country. Gelganyen Kilkayi.' Kununurra: Gelganyen Trust, Kilkayi Trust.

, 2006. 'Gelganyen Trust, Kilkayi Trust: Annual Report April 2005-June 2006.' Kununurra: Gelganyen Trust, Kilkayi Trust.

Gibson, R.B., 2006. 'Sustainability Assessment and Conflict Resolution: Reaching Agreement to Proceed with the Voisey's bay Nickel Mine.' Journal of Cleaner Production 14(3-4): 334-8.

Gibson, G. and D. Kemp, 2008. 'Corporate Engagement with Indigenous Women in the Minerals Industry: Making Space for Theory.' In C. O'Faircheallaigh and S. Ali (eds), Earth Matters: Indigenous Peoples, the Extractive Industries and Corporate Social Responsibility. Sheffield: Greenleaf Publishing.

Hipwell, W., K. Mamen, V. Weitzner and G. Whiteman, 2002. Aboriginal Peoples and Mining in Canada: Consultation, Participation and Prospects for Change. Ottawa: North South Institute.

Innes, L., 2001. 'Staking Claims: Innu Rights and Mining Claims at Voisey's Bay.' Cultural Survival Quarterly 25(1): 12-16.

INTFMA (Innu Nation Task Force on Mining Activities), 1996. Ntesinan Nteshiniminan Nteniunan: Between a Rock and a Hard Place. Sheshatshiu: Innu Nation.

IUCN-ICMM (International Union for the Conservation of Nature and the International Council on Mining and Metals), 2008. 'Mining and Indigenous Peoples Issues Roundtable: Continuing a Dialogue between Indigenous Peoples and Mining Companies.' Viewed on 17 October 2008 at http://www. icmm.com/document/237

Kambel, E.R., 2004. A Guide to Indigenous Women's Rights under the International Convention on the Elimination of All Forms of Discrimination against Women. Forest Peoples Programme. UK: Moreton-in-Marsh.

KLC (Kimberley Land Council), 2008. 'Completed Agreements.' Viewed 18 March 2008 at http://www.klc.org.au/agrees_complete.htm 
Kopasur, P., 2002. 'An Australian Indigenous Women's Perspective: Indigenous life and Mining.' In I. Macdonald and C. Rowland (eds), op. cit.

LIA (Labrador Inuit Association), 2004. 'Labrador Inuit Association Annual Report 2003-2004.' Nain: LIA.

Langton, M., 1998. 'Grandmothers' Law, Company Business and Succession in Changing Aboriginal Land Tenure Systems.' In W.H. Edwards (ed.), Traditional Aboriginal Society. Melbourne: Macmillan.

Lowe, M., 1998. Premature Bonanza: Standoff at Voisey's Bay. Ontario: Between the Lines.

Lukes, S., 1974. Power: A Radical View. London: Macmillan.

Macdonald, I., 2003. 'Tunnel Vision: Women's Rights Undermined.' Paper presented at conference on 'Women in Mining', Madang, 3 August.

Macdonald, I. and C. Rowland (eds), Tunnel Vision: Women, Mining and Communities. Melbourne: Oxfam Community Aid Abroad.

Macintyre, M., 2002. 'Women and Mining Projects in Papua New Guinea: Problems of Consultation, Representation and Women's Rights as Citizens.' In I. Macdonald and C. Rowland (eds), op. cit.

- 2003. 'Petztorme Women: Responding to Change in Lihir, Papua New Guinea.' Oceania 74(1-2): 120-31.

No Dirty Gold, 2008. 'Women and Mining.' Viewed 17 October 2008 at www. nodirtygold.org/disadvantaged_women.cfm

O'Faircheallaigh, C., 2000. The Cape York Model of Project Negotiation. Canberra: Australian Institute for Aboriginal and Torres Strait Islander Studies.

- 2002. A New Model of Policy Evaluation: Mining and Indigenous People. Aldershot: Ashgate Press.

- 2004. 'Evaluating Agreements between Indigenous Peoples and Resource Developers.' In M. Langton, M. Tehan, L. Palmer and K. Shain (eds), Honour Among Nations? Treaties and Agreements with Indigenous People. Melbourne: Melbourne University Press.

, 2005. 'Creating Opportunities for Positive Engagement: Aboriginal People, Government and Resource Development in Australia.' Paper presented at conference on 'Engaging Communities', Brisbane, 12-17 August. 
, 2006a. 'Aborigines, Mining Companies and the State in Contemporary Australia: A New Political Economy or "Business as Usual"?' Australian Journal of Political Science 41(1): 1-22.

- 2006b. Environmental Agreements in Canada: Aboriginal Participation, EIA Follow-Up and Environmental Management of Major Projects. Calgary: Canadian Institute of Resources Law, University of Calgary.

- 2008. 'Negotiating Protection of the Sacred? Aboriginal-Mining Company Agreements in Australia.' Development and Change 39(1): 25-51.

O'Faircheallaigh, C. and T. Corbett, 2005. 'Indigenous Participation in Environmental Management of Mining Projects: The Role of Negotiated Agreements.' Environmental Politics 14(5): 629-47.

Public Policy Forum, 2005. Sharing the Benefits of Resource Developments: A Study of First Nations - Industry Impact Benefits Agreements. Ottawa: Public Policy Forum.

RIMM (International Women and Mining Network), 2004. 'Resolution on Indigenous Peoples and Women.' Viewed 17 October 2008 at www. theminingnewsorg/news.cfm?newsID $=83$

Rio Tinto, 2008. 'Sustainable Development Report Argyle Diamonds 2007.' Viewed 20 October 2008 at www.riotinto.com/documents/ ReportsPublications/2007_Argyle_Diamonds_sustainable_development.pdf

Rose, D.B., 1996. Nourishing Terrains: Australian Aboriginal Views of Landscape and Wilderness. Canberra: Australian Heritage Commission.

—, 2001. 'The Silence and Power of Women.' In P. Brock (ed.), Words and Silences: Aboriginal Women, Politics and Land. Sydney: Allen and Unwin.

Simatauw, M., 2002. 'The Polarisation of the People and the State on the Interests of the Political Economy and Women's Struggle to Defend their Existence: A Critique of Mining Policy in Indonesia.' In I. Macdonald and C. Rowland (eds), op. cit.

UNPFII (United Nations Permanent Forum on Indigenous Issues), 2004. 'Indigenous Women Today: At Risk and a Force for Change.' Viewed 17 October 2008 at www.un.org/hr/indigenousfourm/women/html

Wardlow, H., 2004. 'The Mount Kare Python: Huli Myths and Gendered Fantasies of Agency.' In A. Rumsey and J. Weiner (eds), Mining and Indigenous Lifeworlds in Australia and Papua New Guinea. Wantage: Sean Kingston Publishing. 
Weitzner, V., 2002. Through Indigenous Eyes: Towards Appropriate DecisionMaking Processes Regarding Mining on or Near Ancestral Lands: Final Synthesis Report Phase 1. Ottawa: The North-South Institute.

, 2006. Dealing Full Force: Lutsel K'e Dene First Nation's Experience Negotiating with Mining Companies. Ottawa: North South Institute and Lutsel K'e Dene First Nation. 